\title{
Perlindungan Hukum terhadap Notaris yang Beritikad Baik Membuat Akta Jual Beli Saham dalam Kasus Tindak Pidana Pencucian Uang
}

\author{
Andi Muhammad Rahmat \\ Brawijaya University, Indonesia \\ adhemuhrahmat251@gmail.com
}

\begin{abstract}
This study discusses the legal protection against a notary who has good faith to make the contract of sale with stock in this case of criminal money laundering. To this extent, the study examines the legal protection for notaries who are eligible to be victims from the money laundering cases caused by user services. This study uses normative legal research with statute, philosophical and historical approaches. This study finds that legal protection for notaries referred to Articles 66 and 66A of the Notary Act is essentially tended to internal or administrative measures. Nevertheless, notaries have verschoningsrecht or the right to renegade, another instrument for legal protection in undertaking the Notary Act. The legal protection concept for notaries with the determinate profession on the informant side has been determined limitedly under Article 17 paragraph 1 of the Money Laundering Act.
\end{abstract}

KEYWORDS: Construction, Legal Protection, Notary, Money Laundering.

Copyright $\odot 2019$ by Author(s)

This work is licensed under a Creative Commons Attribution-ShareAlike 4.0 International License. All writings published in this journal are personal views of the authors and do not represent the views of this journal and the author's affiliated institutions.

\section{HOW TO CITE:}

Rahmat, Andi Muhammad. "Perlindungan Hukum terhadap Notaris yang Beritikad Baik Membuat Akta Jual Beli Saham dalam Kasus Tindak Pidana Pencucian Uang” (2019) 6:1 Lentera Hukum 97-116.

Submitted: February 01, 2019 Revised: February 06, 2019 Accepted: March 30, 2019 


\section{PENDAHULUAN}

Pembukaan Undang-Undang Dasar Negara Republik Indonesia Tahun 1945 (UUD 1945) menyatakan perihal tujuan dibentuknya pemerintah negara Indonesia ialah "untuk melindungi bangsa Indonesia dan tumpah darah Indonesia, memakmurkan kesejahteraan umum dan ikut melaksanakan ketertiban dunia." Dalam isi pembukaan UUD1945 terdapat beberapa macam dimensi kehidupan seperti hukum, sosial, kemanusiaan, ekonomi, dan tata cara pergaulan internasional yang wajib terus dipelihara, dijaga, serta dikembangkan sesuai dengan kebutuhan nasional.

UUD 1945 yang menjadi cerminan perkembangan dimensi kehidupan masyarakat sekarang telah mengalami 4 kali perubahan (amandemen), dari tahun 1999-2002 terkait modifikasi struktur kelembagaan yang ada dalam sistem ketatanegaraan Republik Indonesia. Meskipun demikian dengan dimensi kehidupan masyarakatyang di komparasi dengan UUD1945 sebelum amandemen, pada faktanya negara Indonesia meski telah mengalami perubahanUUD 1945 tetap harus menghadapi krisis multidimensi dan perjalanan yang sangat terjal untuk menuju negara yangdemokratis. Nyatanya keberadaan UUD 1945 bukan merupakan jaminan lahirnya negara yang demokratis,namun lebih condong terhadap penciptaan peluang akan tujuan tertentu. Tidak dapat dipungkiri pula dengan kehadiran UUD 1945 yang lebih baik setelah mengalami beberapa kali amandemen,mengisyaratkan bahwa bukan berarti tugas dari konstitusionalitas secara langsung telah selesai. Hal yang menandai adanya tugas negara yang belum rampung ialah adanya hambatan dalam menuju perubahan negara yang lebih baik. Salah satunya ialah praktik korupsi dalam kasus tindak pidana pencucian uang (TPPU).

Ketentuan yang berlaku secara universal mengenai prinsip dasartindak pidana pencucian uang merupakan suatu kejahatan yang mempunyai ciri khas berupa kejahatan tunggal yang secara implisit berbentuk kejahatan ganda. Artinya tindak pidana pencucian uang (money laundering) adalah kejahatan yang bersifat berlanjutan, namun kejahatan utamanya yang disebut sebagai kejahatan asal dengan model penghasilan uang tertentu untuk kemudian dilakukan proses money laundering. ${ }^{1}$

Setiap transaksi memiliki akibat hukum, yang lahir dengan tuntutan kepastian terhadap kaitan hukum dari individu maupun pelaku hukum lainnya. Oleh sebab itukehadiran profesi notarismerupakan suatu bentuk keharusan untuk menanggulangi permasalahan hukum.. Ketertiban,jaminan kepastian dan perlindungan hukum membutuhkan alat bukti tersurat yang memiliki sifat otentik mengenai peristiwa, kejadian, keadaan, atau perbuatan hukum yang dijembatani oleh jabatan notaris. Pencucian uang merupakan strategi dari pelaku tindak pidana untuk menyembunyikan uang hasil tindak pidananya agar seolah-olah berasal dari kegiatan legal.

Black's Law Dictionary memberikan pengertian pencucian uang sebagai Terms used to describe invesment or an another transfer of money flowing that from racketeeting, drug transaction, and other ilegal sources for legitimate channels so it is original source could not be traced (pencucian

Wawan Tunggul Alam, UU Pencucian Uang (1): Anomali Kepastian Hukum (diakses 4 Maret 2015). 
uang adalah istilah untuk menggambarkan investasi di bidang-bidang yang ilegal melalui jalur yang sah, sehingga uang tersebut tidak dapat diketahui lagi asal-usulnya). ${ }^{2}$

Dalam menyelesaikan suatu permasalahan dibutuhkan landasan teori yang tepat dalam penanganannya. Oleh karena itu teori perlindungan hukum akan digunakan sebagai landasan dalam mengkaji terkait permasalahan ini. Perlindungan hukum merupakan pemberian tata cara pelaksanaan terhadap hak asasi manusia (HAM) yang telah dirugikan dari orang lain serta perlindungan itu diperuntukan kepada masyarakat agar mereka dapat menikmati seluruh hak-hak yang diperoleh dari negara atau dengan arti lain perlindungan hukum tersebut merupakan bentuk upaya hukum yang wajib diberikan oleh para penegak hukum supaya menciptakan suasana aman, baik secara pikiran maupun fisik dari berbagai gangguan yang ada dan ancaman yang berasal dari pihak manapun.

Dunia internasional sudah sejak lama berupaya untuk memerangi kejahatan pencucian uang, yang dilakukan oleh negara-negara anggota OECD (Organization for Economic Co-operation and Development) yang membentuk satuan tugas yang disebut (Financial Action Task Force) FATF. Terdapat 40 ketentuan yang telah direkomendasikan oleh organisasi internasional tersebut terhadap seluruh negara termasuk untuk aparat penegak hukum. ${ }^{3}$

Inisiatif pembangunan era anti-money laundering di Indonesia tidak dapat dilepaskan dari dampak masuknya Indonesia ke dalam list NCCTs (Non Cooperative Countries and Territories) oleh (Financial Action Task Force On Money Laundering) atau disingkat FATF pada bulan Juni tahun 2001. Masuknya Indonesia ke dalam daftar, membuat dampak terhadap pemerintah Indonesia harus membentuk suatu lembaga nasional pemerintah yang bernama Pusat Pelaporan Analisis dan Transaksi Keuangan (PPATK) yang menjalin kerja sama dengan KPK (Komisi Pemberantasan Korupsi). Hal ini dilakukan untuk mengetahui dugaantransaksi keuangan yang mencurigakan dari seseorang atau beberapa orang sejak dini. Hal tersebut juga dapat dilakukan baik oleh kepolisian, KPK, kejaksaan, maupun notaris. Maka dari itu untuk mengantisipasi tindak pidana pencucian uang, Departemen Hukum dan HAM (Depkumham) menghimbau notaris agar tidak sembarangan mengeluarkan akta pendirian Perseroan Terbatas (PT). Hal ini dikarenakan banyak pelaku yang menggunakan modus pendirian PT.Kementerian Hukum dan HAM (Kemenkumham) juga menghimbau kepada notaris agar berhati-hati dalam menerbitkan akta jual beli saham. Hal ini dikarenakan ada kemungkinan uang hasil kejahatan dicuci di PT dengan cara pembelian saham. Modus pembelian saham memudahkan pelaku pencucian uang untuk memindahkan uangnya. Jika berbentuk saham, maka otomatis uang hasil kejahatan menjadi sah, sehingga mudah dipindahkan sesuai keinginan pelaku tindak pidana. Notaris selaku pencatat

2 Andi Khamisah Ayu Isnaini, Aminuddin Ilmar, Syamsuddin Muchtar, Kewenangan Notaris dalam Pencegahan Tindak Pidana Pencucian Uang melalui Pembelian Saham, Artikel,(Program Kenotariatan, Fakultas Hukum, Universitas Hasanuddin, Makassar), hlm. 2.

3 Yunus Husein, Upaya Indonesia Untuk Keluar Dari Daftar NCCTs, http://yunushusein.files.wordpress. com/2007/07/32, (diakses 5 Maret 2015). 
besaran modal dan saham dalam akta PT menjadi ujung tombak dalam menyeleksi pendirian perseroan yang dianggap mencurigakan. ${ }^{4}$

Di Indonesia pemberantasanTPPUdimulai sejak Undang-undang No. 15 Tahun 2002 disahkan,(sebagaimana telah diubah menjadi Undang-Undang Nomor 25 Tahun 2003 atas perubahan kedua Undang-Undang Nomor 15 Tahun 2002 Tentang TPPU (UU TPPU), melewati akomodasi Standar Internasional FATF (Financial Action Task Force) maka dimunculkanlah Undang-Undang tentang Pencegahan dan Pemberantasan Tindak Pidana Pencucian Uang (PPTPPU) Nomor 8 Tahun 2010.

Berkaitan dengan pencucian uang, belum terdapat pengertian atau definisi secara universal dan komprehensif. Demikian dalam Undang-Undang PPTPPU, tidak terdapat definisi atau pengertian pencucian uang karena Pasal 1 ayat (l) hanya menyebutkan: "Pencucian uang ialah segala perbuatan yang memenuhi unsur-unsur tindak pidana sesuai dengan ketentuan dalam Undang-undang Nomor 8 Tahun 2010."

Dengan demikian yang dimaksud TPPU oleh Pasal 1 angka 1 ialah segala sesuatu perbuatan yang memenuhi semua unsur-unsur tindak pidana pencucian uang sebagaimana dirumuskan dalam Pasal 3, 4, serta pasal 5 Undang-Undang PPTPPU. ${ }^{6}$ TPPUyang dirumuskan dalam Pasal 3, dan Pasal 4 Undang-Undang PPTPPU merupakan TPPU aktif yang lebih mengedepankan pada penjatuhan sanksi pidana bagi para pelaku pencucian uang sekaligus tindak pidana asalnya dan terhadap pelaku pencucian uang yang terlibat dan mengetahui serta menduga denganmencurigai bahwa hasil harta kekayaan berasal dan bersumber dari perbuatan tindak pidana, sedangkan TPPU yang diberada dalam Pasal 5 Undang-Undang PPTPPU adalah TPPU pasif yang lebih mengutamakan pada pemberian sanksi pidana bagi pelaku yang menikmati hasil dari kejahatan dan bagi pelaku yang juga turut serta berpartisipasi menyembunyikan dan menyamarkan asal usul hasil harta kekayaan.

Dalam penegakan kasus pencucian uang (money laundering) terdapat lembaga khusus yang berfungsi sebagai aparat penyelidik yaitu PPATK. Berdasarkan Pasal 37 Undang-Undang PPTPPU Nomor 8 Tahun 2010, PPATK dalam mengarungi tugas serta kewenangan yang ada harus bersifat mandiri, bebas tidak ada campur tangan dan intervensi serta pengaruh kekuasaan mana pun. PPATK bertanggung jawab kepada kepala pemerintahan yaitu Presiden. Setiap orang atau badan dilarang melakukan segala tindakan sebagai bentuk intervensi menjelang jalannya pelaksanaan tugas dan kewenangan PPATK. Lembaga ini wajib mengabaikan serta menolak segala bentuk wujud intervensi atau campur tangan dari pihak mana pun dalam rangka melaksanakan tugas dan kewenangan yang ada. ${ }^{7}$ Sebelum informasi itu diteruskan kepada penyidik untuk diproses berdasarkan menurut Kitab Undang-undang Hukum Acara Pidana (KUHAP).

\footnotetext{
4 Anonim, Notaris diminta waspadai Pencucian Uang lewat Pembelian Saham, http:/www.hukumonline.com/berita/baca/holl7939/notaris-diminta-waspadai-pencucian-uanglewat-pembelian-saham (diakses 6 Maret 2015).

5 R.Wiyono, Pidana Pencucian Uang, (Jakarta: Sinar Grafika, 2014), hlm. 21.

Ibid., hlm. 23.

7 Undang-Undang Nomor 8 Tahun 2010,
} 
Upaya Pemerintah Indonesia dalam memerangi TPPU bermula dengan dibentuknya dan disahkannya aturan Bank Indonesia (BI) No. 3/10/2001 terkait penerapan Prinsip Mengenal Nasabah atau knowing your costumer. Ketentuan ini merupakan antisipasi atas vakumnya ketentuan hukum setingkat undang-undang mengenai pencucian uang. Setahun kemudian Indonesia memberlakukan dan menerapkan Undang-Undang No. 15 Tahun 2002 terkait Tindak Pidana Pencucian Uang (money laundering), Kemudian dalam hal pemberantasan pencucian uang dibuat Undang-Undang No. 8 Tahun 2010 mengenai Pencegahan Tindak Pidana Pencucian Uang yang berikutnya menggantikan undang-undang sebelumnya, yaitu UndangUndang Nomor 25 Tahun 2003. Semestinya, dengan adanya berbagai macam peraturan perundang-undangan tersebut yang merupakan tindak lanjut dari perjanjian internasional, maka tindak pidana pencucian dapat diatasi oleh pemerintah Indonesia. ${ }^{8}$

Undang-Undang PPTPPU telah mulai diterapkan oleh KPK pada kasus-kasus korupsi para pejabat di negara ini. Melalui lembaga PPATK yang melaporkan adanya indikasi kuat tejadinya TPPUkepada KPK, maka berdasarkan pada keahlian dari penyidik KPK, dapat ditemukan bukti permulaan yang cukup untuk menetapkan pelaku tindak pidana pencucian uang sesuai kasus yang masih dalam proses penyelidikan.Faktanya, jika terjadi perkara tindak pidana pencucian uang, notaris ikut dilibatkan dalam proses pemeriksaan.

Timbul pertanyaan, bagaimana perlindungan hukum terhadap notaris yang beritikad baik dalam pembuatan akta jual beli saham yang terlibat kasus tindak pidana korupsi? Dapatkah notaris melaporkan pelaku yang diduga ingin melakukan tindakan pencucian uang, berkaitan dengan Undang-undang Jabatan Notaris (UUJN) Nomor 2 Pasal 16 huruf (f), tentang kewajiban notaris untuk merahasiakan mengenai akta dan seluruh prosesnya selain kepada para pihak? Bagaimana konstruksi perlindungan hukum terhadap notaris dalam pembuatan akta jual beli saham yang terlibat kasus tindak pidana korupsi? Karena itu peneliti tertarik untuk meneliti mengenai "Konstruksi Perlindungan Hukum Terhadap Notaris Yang Beritikad Baik Membuat Akta Jual Beli Saham dalam Kasus Tindak Pidana Pencucian Uang."

Berdasarkan penjabaran di atas, artikel ini dibagi menjadi dua bagian. Bagian pertama akan membahas perlindungan hukum terhadap notaris yang beritikad baik membuat akta jual beli saham dalam kasus tindak pidana pencucian uang mendapatkan perlindungan hukum. Bagian kedua akan menbahas konstruksi perlindungan hukum terhadap notaris yang menjadi korban dalam kasus tindak pidana pencucian uang.

8 Amrullah M. Arief, Tindak Pidana Pencucian Uang (Money Laundering), (Malang: Bayu Media, 2004), hlm. 20. 


\section{PERLINDUNGAN HUKUM TERHADAP NOTARIS, DI TINJAU DARI UNDANG-UNDANG JABATAN NOTARIS}

Konstruksi tentang pentingnya perlindungan hukum terhadap notaris, yang sesuaidengan perkembangan ilmu hukum dan kebutuhan notaris, dinilai memerlukan sebuah aturan yang mencerminkan sebuah perlindungan, maka disusunlah UUJN sebagai landasan yuridis. Penyusunan UUNJ ini dilakukan karena tuntutan perkembangan ilmu hukum dan kebutuhan masyarakat. UUJN tersebut diharapkan dapat memberikan perlindungan hukum, baik kepada masyarakat maupun terhadap notaris yang diharapkan lebih baik dari pada peraturan perundangan yang digantikannya. Dalam UUJN tersebut telah diatur ketentuan yang berkaitan tentang hak ingkar notaris dan pengawasan terhadap pelaksanaan jabatan notaris.

Berdasarkan Pasal 1 angka 1 UUJN dinyatakan bahwa notaris ialah pejabat umum yang memiliki kewenangan untuk dapat menerbitkan akta otentik, mengenai segala tugas dan wewenang notaris yang ditentukan oleh di dalam aturan undang-undang dan/atau yang diinginkan oleh yang mempunyai kepentingan untuk disebutkan dalam akta otentik. Tujuannya adalah agar akta tersebut dapat digunakan menjadi suatu alat bukti yang kuat jika suatu waktu nanti terjadi perselisihan terhadap para pihak atau adanya gugatan dari pihak lain. Jika hal ini terjadi tidak menutup kemungkinan bahwa notaris akan ikut terkait dalam persoalan tersebut.

Kemudian peranan dan fungsi pejabat notarisdalam pergerakan khususnya pembangunan nasional yang semakin kompleks dalam era ini memiliki perkembangan yang semakin luas dan maju, hal tersebut didukung dan disebabkan adanya kepastian hukum dalam setiap pelayanan dari keluaran produk hukum yang dikeluarkan oleh notaris semakin dinikmati oleh masyarakat, oleh sebab itu pemerintah dan masyarakat secara khusus menyimpan harapan besar kepada setiap individu maupun kelompok pejabat notaris, agar senantiasa jasa yang diberikan oleh pejabat ini benar-benar mempunyai citra nilai yang tinggi atau berkualiatas serta bobot yang dapat diandalkan secara umum dalam peningkatan perkembangan hukum nasional.

Wujud pengaplikasian ketentuan dari fungsi dan peranan notaris, maka dibutuhkan notaris yang memiliki kualitas baik dari segi iman, moral, ilmu, maupun rasa ketakwaaan serta menegakkan secara tinggi keluhuran nama baik, harkat dan martabat notaris dalam menyediakan pelayanan jasa hukum kepada masyarakat secara luas. Oleh sebab itu profesi ini memiliki kewajiban untuk mampu memberikan pelayanan secara baik atau dengan profesionalitas yang tinggi, sebab jasa notaris dinilaikrusial bagi kepentingan masyarakat. Bila seorang pejabat notaris dianggap tidak mampu dalam menjalan fungsinya untuk memberikan pelayanan yang baik atau tidak bertindak secara professional menurut aturannya, maka akan banyak didapatkan pihak-pihak yang dirugikan dari dampak kelalain atau kesalahan yang telah diperbuat oleh pejabat.

Berbicara tentang perlindungan hukum kepada pejabat notaris ${ }^{9}$ ditinjau dari aspek kepidanaan bisa sangatlah berlainan dengan perlindungan hukum apabila kita

9 Habib Adjie, Kumpulan Tulisan Tentang Notaris, (Bandung: Mandar Maju, 2010), hlm. 59. 
melihat dan ditinjau dari segi UUJN. Aspek perlindungan hukum terhadap notaris terkait dengan hubungan pranata hukum pidana yang lebih bersifat ekstern, dalam pengertiannya bahwa sekiranya notaris sebagai pejabat umum yang mempunyaihakhak istimewa sebagai konsekuensi predikat kedudukan jabatan yang dimilikinya. Hakhak istimewa yang didapatkan oleh notaris, menjadi faktor pembeda perlakuan (treatment) kepada masyarakat biasa. Bentuk-bentuk perlakuan itu diantaranya ialahsehubungan dengan hak ingkar notaris yang harus diindahkan, perlakuan dalam hal pemanggilan, pemeriksaan, proses penyelidikan dan penyidikan.

Ada pertimbangan yuridis yang harus diperhatikan dalam menjalankan fungsi dan tugas jabatan notaris, yaitu sebagai berikut: 1 . Notaris merupakan pejabat publik yang bertugas untuk menjalankan jabatan publik; 2. Notaris dalam menjalankan amanahnya tidak boleh mencemarkan nama baik organisasi atau korps pengembang profesi hukum; 3. Notaris dalam menjalankan tugasnya tidak boleh mencemarkan nama baik dari lembaga Kenotariatan; 4. Karena notaris bekerja dengan mengimplementasikan hukum didalam produk yang dihasilkannya, maka kode etik ini diharapkan senantiasa dapat mengingatkan fungsi jabatan seorang notaris untuk senantiasa menjunjung tinggi keseluruhan martabat dan tugas jabatannya, serta mampu menjalankan tugas dengan memenuhi persyaratan yang telah ditetapkan oleh perundang-undangan.

\section{A. Penjelasan Pasal 1320 KUHPerdata}

Sahnya suatu pembuatan perjanjian harus berpedoman pada Pasal 1320 KUHPerdata. Pasal 1320 KUHPerdata mempunyai empat syarat sahnya suatu perjanjian, yaitu, kecakapan untuk membuat suatu perikatan, sepakat mereka yang mengikat dirinya, suatu sebab yang halal, dan hal tertentu.

\section{B. Asas Perjanjian}

Terdapat 7 jenis-jenis asas hukum perjanjian yang merupakan bagian dari asas-asas atau aturan umum yang harus diperhatikan seksama oleh setiap pihak yang terkait di dalamnya. Pertama asas hukum sistem terbuka hukum perjanjian, kedua asas konsesualitas, ketiga, asas personalitas, keempat asas itikad baik, kelima asas pacta sunt servada, keenam asas force majeur, ketujuh asas exeptio non adiemletie contractus.

\section{Analisis Undang-undang No. 8 Tahun 2010 Tentang Pencegahan dan Pemberantasan Tindak Pidana Pencucian Uang 1. Anaisis hukum pidana materil}

Asas umum hukum pidana yang dianut secara universal sampai saat ini adalah asas legalitas. Asas legalitas selain menciptakan kepastian hukum dan larangan berlaku retroaktif (asas non-retroaktif) dan mencegah multitafsir atas ketentuan Undangundang Pidana dan menegaskan bahwa sumber hukum pidana adalah hukum tertulis 
(undang-undang). Analisis hukum UU TPPU membahas ketentuan Pasal 2 sampai dengan Pasal 10.

\section{Analisis hukum pidana formil}

KUHAP dalam tataran hukum pidana formil sebagai legal generali mengkalsifikasikan bentuk perkara pidana yang dianggap serius seperti perkara korupsi, pencucian uang, dan perkara narkoba serta perkara terorisme. Disini dinyatakan secara jelas dalam Pasal 103 KUHP. ${ }^{10}$ Yang dengan konkrit menjelaskan bentuk penyimpangan yang bersifat khusus dalam tataran UU TPPU yang mempunyai dampak terhadap makna hukum formil yang secara tidak langsung menyimpang dari ketentuan KUHAP.

Dalam konteks ini, dapat dikelompokkan kedalam dua jenis pelanggaran terhadap asas-asas dan fungsi hukum yang baku. Penyimpangan pertama yakni terhadap fungsi hukum pidana ultium remedium. Seperti pendapat Blunt yang mengemukakan bahwa penyimpangan memgenai hal-hal khusus diperbolehkan asal menghadapi keadaan-keadaan sebagai berikut:

(a) Korban karena kejahatan sangat besar;

(b) Terdakwa residivis; dan

(c) Kerugian korban tidak dapat dipulihkan. ${ }^{11}$

Pendapat Blunt tersebut sangat relevan membahas implementasi UU TPPU dan dampaknya dalam konteks iklim keuangan dan perbankan di Indonesia.Penyimpangan kedua, ditandai dengan penandaan bukti proof beyond reasonable doubt, yakni menggunakan metode pembuktian terbalik murni (genuine reversal of burden of proof) atas semua harta yang disinyalir hasil dari kejahatan pencucian uang dalam tataran probable cause principle atau presumptive evifdence dan mengesampingkan sufficient evidence principle atau prima facie evidence. ${ }^{12}$

Hukum Acara Pidana dalam UU TPPU 2 diatur dalam Bab VIII di bawah judul Penuntutan, Penyidikan dan Pemeriksaan oleh Pengadilan yang terdiri dari 14 pasal, dan dikelompokkan menjadi empat bagian.

\section{Proses Pencucian Uang Dalam Jual Beli Saham}

10 Perlu dipahami bahwa ketentuan Pasal 103 KUHP merupakan alas hukum (hak) negara untuk mengkriminalisasi perbuatan-perbuatan yang belum diatur dalam KUHP atau tidak ada padanannya di dalam KUHP baik dari sisi normatif maupun ancaman sanksi pidananya atau sanksi pidana dalam KUHP tidak relevan dengan perkembangan masyarakatnya. Ketentuan Pasal 103 KUHP harus dibedakan dengan asas hukum "lex specialis derogate lege generali" dan asas concursus (perbarengan tindak pidana) dalam Pasal 63 ayat (2) yang berbunyi: "Jika suatu perbuatan masuk dalam suatu aturan pidana yang umum, diatur pula dalam aturan pidana yang khusus, maka yang khusus itulah yang diterapkan."

Il Romli Atmasasmita, Globalisasi dan Kejahatan Bisnis, (Jakarta: Prenada, 2010), hlm. 192.

12 Sufficient evidence: A standard for reviewing a criminal conviction on appeal, based on whether enough evidence exist to justify the fact-trier's finding of guilt beyond reasonable doubt. Prima facie evidence: evidence that will establish a factor sustain a judgment unless contradictor evidence is produced. Presumptive evidence: Evidence deem true and sufficient unless distrected by other evidence. Lihat Bryan Gamer, Black's Law Dictioary, second Pocket Edition, Eagan: West Publishing, 1966, p. 253,551,678. 
Secara umum dapat dijelaskan bahwa proses aktivitas pencucian uang (money laundering) merupakan suatu perbuatan, dengan menggunakan, memindahkan dan melakukan tindakan lainnya atas hasil dari suatu tindak pidana yang sering dilakukan oleh kelompok kejahatan (criminal organization), maupun individu yang melakukan tindakan semisal korupsi, penyuapan, dan perdagangan narkotika serta tindak pidana lainnya dengan tujuan untuk menyamarkan, menyembunyikan atau mengaburkan asalusul uang yang bersumber dari tindak pidana. ${ }^{13}$

Salah satu modus pengguna jasa pelaku pencucian uang dalam jual beli saham ialah dengan memanfaatkan fungsi notaris sebagai pejabat umum yang mempunyai hak membuat suatu Akta Otentik atau sebagai pencatat besarnya modal dan saham dalam pembuatan akta PT Franklin Jurador menjelaskan proses penggelapan uang hasil kejahatan ke bisnis yang legal ditempuh dalam berbagai macam transaksi jual beli saham dengan mengajukan aset fiktif atau penitipan fiktif untuk keperluan dan kepentingan investasi, yang dapat melibatkan banyak pihak, bukan hanya dalam negeri namun juga international antar negara, dengan metode-metode transaksi yang dirasa cukup rumit. Sehingga para pelaku atau pengguna jasa dengan mudah menyamarkan atau menyembunyikan harta kekayaan yang di peroleh dari cara yang ilegal. Seperti contoh kasus yang dijelaskan sebelumnya dimana Muhammad Nazaruddin menggunakan uang hasil kejahatan tindak pidana korupsi terkait pemenangan PT DGI sebagai pelaksana proyek terkait pembangunan wisma atlet SEA Games 2011 kemudian melakukan pencucian uang dengan membeli saham di PT Garuda Indonesia.

Kegiatan pencucian uang dapat menggunakan sarana pasar modal dengan membeli efek-efek yang ditawarkan. ${ }^{14}$ Juga dapat dengan pembelian saham di perusahaan-perusahaan tertutup. Dalam hal jual beli dilakukan dalam Perseroan tertutup sesuai Pasal 49 Undang-Undang Perseroan Terbatas ditentukan, pemindahan hak terkait saham atas nama dilakukan dengan akta pemindahan hak, baik yang dibuat dihadapan notaris maupun di bawah tangan. ${ }^{15}$

Keberagaman model kegiatan pencucian uang yang paling sering dilakukan ialah penerapan failitas wire transfer. Fasilitas ini merupakan sebuah alternatif yang dapat digunakan dalam pengaplikasian pencucian dengan prosedur yang sistematis seperti placement, layering dan integration. Namun seiring berkembangnya zaman, industri perbankan mampu membuat sebuah terobosan untuk menanggulangi pencucian yang telah marak terjadi dengan konsep cyberpayments. Konsep terbaru yang merupakan andalan industri perbankan ini berguna untuk menggantikan prosedur lama yang sudah banyak dijadikan celah oleh pelaku pencucian uang. Adapun unggulan program terbaru ini adalah mempunyai kualitas material yang tinggi dengan akses yang fleksibel untuk para nasabahnya. Disamping kelebihan yang dimiliki cyberpayments juga memiliki

13 Halim Pathorang. Penegakan Hukum Terhadap Kejahatan Pencucian Uang di Era Globalisasi, (Jakarta: Total Media 2013), hlm. 94.

14 Ibid, hlm. 96.

15 Abdulkadir Muhammad, Hukum Dagang tentang Surat-Surat Berharga, (Bandung: PT Citra Aditya Bakti 2013), hlm 23. 
kelemahan ketika pelaku pencucian uang menggunakan data anonim untuk memanipulasi dana hasil kejahatan. ${ }^{16}$

Meski industri perbankan telah meciptakan sistem cyberpayments untuk menangkal adanya tidak kejahatan pencucian uang, nyatanya para pelaku tidak kehilangan cara untuk melakukan aksinya yang ditunjang dengan kecanggihan teknologi era sekarang. Oleh sebab itu dibutuhkan upaya penegakan regulasi yang kemuadian mampu mencegah dan menanggulangi permasalahan tersebut menggunakan capacity building oleh para penegak hukum Indonesia. Tahapan paling utama untuk menangani hal ini sejatinya terletak pada konteks placement, layering dan integration yang saling berkesinambungan. Karena tahapan tersebut merupakan satu kesatuan yang kemudian akan saling berkaitan satu sama lain, yang biasanya penemuan kasus tindak pidana pencucian uang akan terungkap pada tahap layering. ${ }^{17}$

Dapat dibayangkan apa yang terjadi apabila notaris lalai karena jasanya dimanfaatkan oleh para pengguna jasa untuk melakukan suatu perbuatan melawan hukum atau apa yang terjadi manakala terdapat notaris maupun PPAT yang secara sadar membantu proses terjadinya suatu perbuatan melawan hukum terkait pembuatan akta sesuai kewenangannya. Resiko yang akan dihadapi bukan hanya yang bersangkutan berurusan dengan proses pidana, tetapi juga bisa berdampak pada menurunnya kredibilitas dan kehormatan profesi secara keseluruhan. Dari penjelesan tersebut profesi notaris ini seyogiyanya dapat menahan diri dari turut serta secara tidak langsung melibatkan profesinya pada tindak pidana pencucuian uang, karena pada dasarnya aturan yang sudah ada kurang begitu melindungi profesi ini dari kekhilafan yang dapat merugikan kredibilitas dari pekerjaan ini.

\section{E. Contoh Kasus}

Perkara mengenai pencucian uang di Indonesia kian mengalami perkembangan seiring dengan perkembangan era yang semakin modern, hal ini pun juga termasuk dalam penanganan kasus tindak pidana korupsi yang akhir-akhir ini dilakukan oleh para pejabat negara ataupun korporasi. Mirisnya hal tersebut masih tidak dapat diakomodasi dengan baik melalui Undang-Undang PPTPPU. ${ }^{18}$ Identifikasi kasus ini dapat dilihat dalam kasus suap Wa Ode Nurhayati, dalam transaksi yang telah masuk rekeningnya yang dirangkum dalam Hasil Pemeriksaan dan Laporan Hasil Transaksi Keuangan Mencurigakan. Berlandaskan Pasal 1 angka 7 Undang-UndangPPTPPU, Laporan Hasil Pemeriksaan ialah hasil dari proses identifikasi suatu masalah, analisis, pengawasan, dan hasil evaluasi terkait Transaksi Keuangan Mencurigakan yang telah ditenggarai dan dikerjakan secara objektif, independen serta profesional untuk menilai dugaan adanya sebuah tindak pidana. Laporan Hasil Pemeriksaan tersebut pada

16 Edi Nasution, Artikel, Memahami Praktik Pencucian Uang Hasil Kejahatan, www.ppatk.go.id/, (Diakses 15 November 2012), hlm. 5.

17 Ibid., hlm. 6.

18 Aswandi, "Penegakan Hukum Tindak Pidana Korupsi yang Berbarengan Dengan Tindak Pidana Pencucian Uang (Concurus Realis)", Jurnal, (Fakultas Hukum, Magister Ilmu Hukum, Universitas Tanjungpura, 2013), hlm. 7. 
dasarnya ialah penajaman, pencarian atau pendalaman dari Laporan Hasil Transaksi Tunai dan Laporan Hasil Keuangan Mencurigakan. ${ }^{19}$

Ketiga dokumen tersebut dalam laporan hasil PPATK ini belum dapat dijadikan sebagai sebuah alat bukti. Terlebih pada tingkatan penyidikan ketika banyak hal belum mendapat kebenaran secara yuridis. Kebocoran atau "tipping off" atas laporan PPATK tersebut merupakan suatu tindak pidana tersendiri sebagaimana tertulis isi dari Pasal 12 ayat (3) Undang-Undang PPTPPU: "Pejabat atau pegawai PPATK atau Lembaga Pengawas dan Pengatur dilarang menyampaikan laporan Transaksi Keuangan Mencurigakan yang akan atau ingin dilaporkan kepada PPATK secara langsung maupun tidak langsung dengan cara apapun terhadap Pengguna Jasa atau pihak lain. Sesuai pada ayat (5) perbuatan ini diancam dengan pidana penjara paling lama 5 (lima) tahun dan denda paling banyak Rpl.000.000.000.- (satu miliar rupiah)". ${ }^{20}$

Bahkan menurut informasi di Bareskrim Mabes Polri sedemikian rahasianya dan tertutupnya Laporan dari PPATK, disposisi oleh Kabareskrim ini hanya dapat dilakukan tanpa harus membuka segel dari amplopnya. Keterangan disposisi tersebut hingga ke struktur terbawah dilakukan dalam amplop yang tertutup hingga selanjutnya dibuka oleh ketua tim penyidik. Ruang tempat penyimpanan harus dilindungi sedemikian ketat hingga bisa setara dengan perlindungan uang pada bankbank besar yang terdapat di tanah air (ruang khasanah). Sangatlah klise setiap mengingat kejahatan keuangan khususnya berupa kejahatan tindak pidana korupsi (tipikor) dapat sangat memungkinkan para pelaku melakukan pencucian uang (money laundering) terhadap kekayaan hasil perbuatannya tersebut.

\section{Konstruksi perlindungan hukum terhadap notaris yang menjadi korban dalam kasus tindak pidana pencucian uang}

Menurut pernyataan Peter Yam Tat-wing, Asisten Komisioner Pidana Kepolisian di Hong-Kong, bahwa kejahatan yang terorganisasi misalnya pencucian uang tidak dapat diberantas secara efektif kecuali dengan dibuatnya suatu kerjasama yang efisien dan efektif antar institusi atau lembaga, maupun institusi berbagai macam jurisdiksi yang bekerja sama untuk menuntaskan kasus pencucian uang (money laundering). Kerja sama menjadi kata kunci terakhir untuk menjalankan strategi pencegahan dan pemberantasan pencucian uang, khususnya di Indonesia. ${ }^{21}$ Tidak bisa dipungkiri bahwa salah satu kunci keberhasilan suatu negara dalam tindakan untuk mencegah dan memberantas Tindak Pidana Pencucian Uang (money laundering crimes) ialah dalam

19 Ibid., hlm. 8 .

20 Ibid., hlm. 9.

21 Peter Yam Tat-wing, Components of an effective anti-money laundering regime, (http://www.unafei.or.jp/english/pdf/RS_No58/No58_05VE_Tat-wingl.pdf/), 23/01/2017, (diakses 28 November 2018) 
keikutsertaan masyarakat terutama pihak pelapor dalam membantu aparat penegak hukum. ${ }^{22}$

Namun sudut pandang gambaran dari UUJBN, tidak ada satu pun pasal yang menyatakan bahwa dalam undang-undang ini yang mengatur tentang profesi notaris mempunyai kewajiban untuk segera melaporkan kepada aparat penegak hukum berkenaan dengan setiap adanya bentuk transaksi keuangan yang dilihat dan dianggap mencurigakan kepada penghadapnya, untuk hal tersebut menjadi inisiatif dari pihak notaris itu sendiri dengan aturan apabila notaris hendak melaporkan bila ada transaksi mencurigakan terhadap klien atau penghadapnya, maka profesi ini bertindak sebagai pelapor harus membawa pribadi secara sendiri atau dengan kata lain sebagai masyarakat biasa dan harus meletakkan profesinya selaku Notaris Pejabat Pembuat Akta Tanah atau pejabat Publik. ${ }^{23}$

Laporan yang diberikan oleh pelapor kepada aparat penegak hukum secara tidak langsung laporan tersebut merupakan perbuatan dengan tingkat resiko yang cukup besar serta berdampak secara langsung terhadap keselamatan dirinya, keluarganya serta harta benda miliknya berdampak denga Negara harus menciptakan sebuah tindakan berupa pemberian kepastian hukum tentang perlindungan yang diberikan kepada pelapor beserta hal penting lainnya. Perlindungan hukum bagi pelapor atas tindakan transaksi keuangan mencurigakan yang berhubung dengan tindak pidana pencucian uang dapat dibagi menjadi dua hal seperti sebelum dan sesudah berlakunya Tindak Pidana Pencucian Uang. Sebelum berlakunya Tindak Pidana ini, perlindungan atas hak-hak pelapor dituangkan dalam Undang-Undang Nomor 13 Tahun 2006 Tentang Perlindungan Saksi dan Korban. ${ }^{24}$

Ketentuan yang berkenaan dalam perlindungan khusus dituliskan secara eksplisit dalam pasal 2 Peraturan Pemerintah (PP) No. 57 Tahun 2003 yang mendukung bahwa bagi para pelapor dan Saksi dalam kasus perkara tindak pidana money laundering mempunyai hak istimewa seperti diperolehnya perlindungan secara khusus baik sebelum, selama ataupun setelah proses pemeriksaan perkara kasus pidana. Perlindungan terkait dengan keamanan pribadi dari ancaman langsung maupun tidak langsung terhadap mental dan fisik, perlindungan terhadap harta kekayaan, kerahasiaan dan penyamaran identitas dan memberikan keterangan tanpa bertatap muka secara langsung tidak diperlukan dengan tersangka atau terdakwa pada setiap tingkatan proses pemeriksaan suatu perkara merupakan bentuk perlindungan yang khusus. $^{25}$

Selanjutnya mengenai teknis pelaksanaan dari hal tersebut, telah dituangkan dalam Peraturan KAPOLRI Nomor 17 Tahun 2005 mengenai Tata Cara Perlindungan

\footnotetext{
22 I Made Darmawan, Perlindungan Hukum Bagi Notaris atas Tindak Pidana Pencucian Uang yang Dilakukan Oleh Penghadapnya, Jurnal(Fakultas Hukum, Universitas Pamulang, 2017), hlm. 10.

23 Ibid., hlm. 10.

24 Secara khusus Undang-Undang Perlindungan Saksi dan Korban tidak mengatur mengenai perlindungan bagi Pelapor, tetapi ketentuan yang ada dalam Undang-Undang ini berlaku untuk saksi dan korban semua tindak pidana termasuk tindak pidana pencucian uang.

25 Pasal 5 Peraturan Pemerintah Nomor 57 Tahun 2003
} 
Khusus Bagi Pelapor dan Saksi Dalam TPPU. Wujud perlindungan yang disediakan oleh aparat instansi Kepolisian negara untuk menciptakan rasa aman terhadap diri pelapor atau saksi dari adanya kemungkinan yang bisa membahayakan diri, jiwa atau harta termasuk keluarganya. Pemohon perlindungan khusus ialah pelapor, saksi, PPATK, Penyidik, Penuntut Umum atau hakim merupakan perlindungan khusus menurut Peraturan KAPOLRI. ${ }^{26}$ Dalam hal ini diperlukan adanya Konstruksi Perlindungan Hukum untuk kiranya bisa melindungi notaris yang mempunyai itikad baik dalam pembuatan akta jul beli yang menjadi korban oleh pengguna jasa dalam kasus tindak pidana pencucian uang.

\section{F. Bentuk Perlindungan Ikatan Notaris Indonesia terhadap Anggota yang}

\section{Terlibat Kasus Tindak Pidana}

Ikatan Notaris Indonesia (INI) merupakan suatu wadah perkumpulan/organisasi notaris yang didirikan pada tanggal 1 Juli 1908, lalu diakui dan disahkan sebagai Badan Hukum (rechtspersoon) berdasarkan Gouvernements Besluit (Penetapan Pemerintah) pada tanggal 5 September 1908 No. 9, merupakan satu-satunya alat pemersatu bagi semua elemen dan setiap orang yang memiliki serta menjalankan tugas jabatan ini sebagai pejabat umum di Indonesia sesuai dengan fungsinya, sebagaimana hal ini telah dilegalkan dan mendapatkan pengesahan dari pemerintah yang berdasar dari Anggaran Dasar Perkumpulan Notaris yang telah mendapatkan pengesahan Penetapan Menteri Kehakiman pada tanggal 4 Desember 1958 Nomor J.A.5/117/6 dan diumumkan dalam Berita Negara Republik Indonesia tanggal 6 Maret 1959 Nomor 19. ${ }^{27}$

Dalam hal tersebut INI hanya melakukan pengawasan tata cara penegakan kode etik, dijelaskan dibagian pertama dalam Pasal 7 tentang pengawasan, ${ }^{28}$ kemudian pada bagian kedua dalam Pasal 8 tentang pemeriksaan dan penjatuhan sanksi. ${ }^{29}$

26 S., I Made Darmawan, supra note $22 \mathrm{hlm} .12$.

27 https://www.ini.id/apps/public/file/kode_etik/Perubahan_KEN_hasil_KLB_2015. Tambahan Berita Negara Republik Indonesia Nomor 6, dan perubahan anggaran dasar yang terakhir telah mendapat persetujuan dari Menteri Hukum dan Hak Asasi Manusia Republik Indonesia berdasarkan Surat Keputusan tanggal 12 Januari 2009 Nomor AHU-03.AH.01.07. Tahun 2009, oleh karena itu sebagai dan merupakan organisasi Notaris sebagaimana yang dimaksud dalam Undang-Undang Nomor 30 Tahun 2004 tentang Jabatan Notaris yang diundangkan berdasarkan Lembaran Negara Republik Indonesia Tahun 2004 Nomor 117, Tambahan Lembaran Negara Republik Indonesia Nomor 4432 serta mulai berlaku pada tanggal 6 Oktober 2004, sebagaimana telah diubah dengan Undang-Undang Nomor 2 Tahun 2014 tentang Perubahan Atas Undang-Undang Nomor 30 Tahun 2004 tentang Jabatan Notaris yang telah diundangkan dalam Lembaran Negara Tahun 2014 Nomor 3, Tambahan Lembaran Negara Nomor 5491 (selanjutnya disebut "Undang-Undang Jabatan Notaris")

28 https://www.ini.id/apps/public/file/kode_etik/Perubahan_KEN_hasil_KLB_2015. Pasal 7, pengawasan Tata Cara Penegakan Kode Etik. Pengawasan atas pelaksanaan Kōe Etik dilakukan oleh: Pengurus Daerah dan Dewan Kehormatan Daerah pada tingkat Kabupaten/Kota, Pengurus Wilayah dan Dewan Kehormatan Wilayah pada tingkat Propinsi, Pengurus Pusat dan Dewan Kehormatan Pusat pada tingkat National.

29 Dewan Kehormatan Daerah/Dewan Kehormatan Wilayah/Dewan Kehormatan Pusat berhak menduga dan mencari pokok dugaan Pelanggaran Kode Etik oleh anggota Perkumpulan dengan usaha para anggota yang menanungi setelah proses pengaduan tertulis atas dasar bukti nyata yang telah diberikan. 
Memegang erat kode etik notaris maka akan berkaitan a dengan proses dalam menjalakan tugas jabatan secara profesional, karena dengan aturan itulah bisa diketahui segala perilaku yang wajib dimiliki oleh seorang yang berprofesi sebagai Notaris. Dengan profesi hukum erat kaitannya dengan etika bahwa etika profesi disini yang dimaksud sebagai suatu sikap dalam menjalani hidup yang berbentuk ketersediaan dalam pelaksanaan penyediaan pelayanan profesional di bidang khususnya hukum terhadap masyarakat dengan keterlibatan/keterkaitan yang penuh dengan keahlian penuh sebagai pelayanan dalam rangka pelaksanaan tugas berupa kewajiban profesi ini terhadap masyarakat yang membutuhkan atau mencari pelayanan hukum.

Tidak ada satupun pasal yang tertera secara khusus untuk mengatur tentang perlindungan hukum terhadap notaris apabila terlibat kasus tindak pidana. Tetapi pada hakekatnya perlindungan hukum ini hanya tersirat dalam Pasal ke 66 sampai denga 66A UUJN serta undang-undang lainnya yaitu tentang Perlindungan Konsumen Pasal 6 ayat (2) Hak untuk mendapatkan perlindungan hukum dari tindakan konsumen yang beritikad tidak baik. ${ }^{30}$

\section{G. Dampak dari Akibat Tindak Pidana Pencucian Uang}

Adapun dampak atau akibat dari pencucian uang (money laundering) sebagai berikut, Undermining the legitimate private sectors dengan arti merongrong/menggerogoti sektor swasta yang sah, Reputation risk berarti mengakibatkan rusaknya reputasi negara, Loss revenue atau mengurangi suatu pendapatan dari negara yang bersumber dari pembayaran pajak, Undermining the integrity of finacial markets memiliki arti merongrong/menggerogoti integritas pasar keuangan, Risk of privatization efforts dengan kata lain membahayakan usaha dari privatisasi perusahaan yang dilakukan oleh pemerintah yang berasal dari negara, Social cost berdampak pada biaya sosial yang tinggi, Economic distortion and instability Memunculkan distorsi serta ketidakstabilan ekonomi, Loss of control of economic policy atau mengakibatkan hilangnya kontrol pemerintah atas kebijakan ekonominya, dan Berdampak pada kurangnya kepercayaan kepada pasar dan penggelapan (embezzlement) serta terjadinya penipuan (fraud).

\section{H. Pencegahan Tindak Pidana Pencucian Uang}

Dalam praktik jual beli saham yang umumnya terjadi melalui akta Notaris dengan mempergunakan model akta yang hampir serupa sebagaimana perjanjian jual beli umumnya. ${ }^{31}$ Ketika ada profil atau partikularitas yang menyimpang dari pengguna jasa notaris, disinilah peran notaris untuk mencegah tindak pidana pencucian uang. Notaris perlu dengan cermat memperhatikan apa yang disebut sebagai perilaku dari profesi ini

\footnotetext{
30 Pasal 6 Undang-undang Nomor 8 Tahun 1999 Tentang Perlindungan Konsumen

31 Prasetya Rudhi, Teori dan Praktek Persroan Terbatas, Sinar Grafika, Jakarta, 201l), hlm. 20.
} 
yang memiliki integritas moral yang kokoh, harus memiliki kejujuran intelektual, sadar akan batas kewenangan dan tidak semata-mata karena pertimbangan uang. ${ }^{32}$

Mengenai identifikasi pengguna jasa telah diterapkan oleh notaris dalam setiap proses pembuatan akta. Dalam pembuatan akta, notaris akan meminta minimal dua bukti identitas diri dari penghadap kemudian mencocokkan nama dan tanda tangan penghadap yang tertera dikedua bukti identitas dirinya. Namun mengenai verifikasi data, notaris menolak melakukannya karena menurut notaris hal demikian bukan kewenangan notaris. Notaris adalah jabatan kepercayaan maka notaris tidak dapat menyelidiki kebenaran dari identitas penghadap, notaris hanya mendengar dari pengakuan para penghadap.

Untuk membantu pemerintah mencegah bentuk tindak pidana pencucian uang. Notaris dalam hal peralihan saham akan membuat surat pernyataan bagi penghadap bahwa uang yang akan atau telah disetor bukan merupakan uang dari hasil suatu tindak pidana pencucian uang dan kejahatan lainnya. Notaris merupakan sebuah fungsi jabatan kepercayaan. Masyarakat mempercayakan kepada notaris untuk membuat perjanjian yang termuat dalam akta notaris. Akta Notaris ialah sebuah akta otentik yang dapat menjadi sebuah alat bukti yang bisa dikatakan sempurna dalam hal ini bahwa akta otentik tidaklah memerlukan lagi penambahan pembuktian. ${ }^{33}$

Ketika notaris menyadari adanya transaksi keuangan mencurigakan, notaris harus melaporkan kepada PPATK. Notaris belum memahami tentang bagaimana proses laporan atas transaksi keuangan mencurigakan. Perlu kita ketahui, bahwa pelaporan oleh notaris terkait transaksi keuangan mencurigakan yang telah dilakukan pengguna jasa kepada PPATK tidak berarti bahwa telah terjadi suatu tindak pidana pencucian uang melalui pembuatan aktanya. Adalah kewajiban PPATK, berdasarkan analisisnya, untuk menyimpulkan suatu transaksi yang dirasa menyimpang dari profil atau partikularitas pengguna jasa merupakan suatu transaksi yang wajar serta menggunakan uang yang sah. ${ }^{34}$ Jadi ketika ada pembelian saham yang menyimpang dari profil, serta karakteristik pengguna jasa cukup laporkan saja ke PPATK. Notaris menginginkan adanya aturan yang jelas mengenai kewenangan notaris dalam hal pencegahan tindak pidana pencucian uang. Jika tidak ada batasan yang jelas atas kewenangan notaris untuk mencegah atau mengatasi tindak pidana pencucian uang maka beban notaris tidak terukur. Kewenangan dari profesi ini yang akan ditentukan kemudian berdasarkan dengan aturan hukum lain yang akan muncul di kemudian hari (ius constituendum) harus dalam bentuk peraturan perundang-undangan. ${ }^{35}$ Notaris sebagai pejabat umum (openbaar ambtenaar) yang memiliki fungsi kewenangan dalam

32 Habib Adjie, Hukum Notaris Indonesia Tafsir Tematik Terhadap UU No. 30 Tahun 2004 tentang Jabatan Notaris, (Bandung: Refika Aditama 2009), hlm. 43.

33 Subekti R, Hukum Pembuktian, (Jakarta: Pradnya Paramita, 2005), hlm. 24.

34 Yustiavandana Ivan. Arman Nevi. Adiwarman, Tindak Pidana Pencucian Uang di Pasar Modal, (Bogor: Ghalia Indonsia 2010), hlm. 11.

35 Habib Adjie, Hukum Notaris Indonesia Tafsir Tematik Terhadap UU No. 30 Tahun 2004 tentang Jabatan Notaris, Bandung: Refika Aditama, 2009, hlm. 45. 
pembuatan akta otentik dapat dibebankan tanggung jawab atas perbuatannya berkaitan dengan profesinya dalam membuat akta. ${ }^{36}$

Jika notaris tidak melaporkan Transaksi Keuangan Mencurigakan dan ternyata terjadi kejahatan, seorang Notaris bisa menghadapi ancaman pidana Pasal 5 UndangUndang PPTPPU mengenai tindak pidana pencucian uang pasif, serta Pasal 55 KUHP yakni turut serta dan Pasal 56 KUHP yakni ikut aktif membantu kejahatan. Mempidanakan notaris harus berdasarkan pada aspek yang harus diperhatikan ketika akan membuat akta yakni lahiriah, formal, dan materil. Namun jika tanpa pembuktian disertai penelitian yang dikerjakan secara mendalam dengan mencoba menemukan unsur dari kesengajaan, keteledoran atau kesalahan dari pejabat notaris, sebab hal itu merupakan suatu tindakan yang tanpa adanya dasar hukum yang secara tegas tidak dapat dipertanggung jawabkan. ${ }^{37}$

\section{Konstruksi Perlindungan Hukum}

Menurut Undang-Undang Nomor 2 Tahun 2014 junto Undang-undang Nomor 30 Tahun 2004 mengenai Peraturan Jabatan Notaris tidak ada satupun pasal yang tertera dan tertuang yang secara khusus mengatur tentang perlindungan hukum atas diri notaris. Tetapi pada hakekatnya perlindungan hukum ini hanya tersirat dalam Pasal ke 66 sampai dengan 66A UUJN. ${ }^{38}$ Sehingga perlindungan hukum kepada Notaris yang diilhami dari UUJN, yaitu Undang-undang Nomor 2 Tahun 2014 junto UndangUndang Nomor 30 Tahun 2004 tentang Jabatan Notaris hanya membahas tentang proses terhadap sebuah pengawasan atas diri Notaris yang dilakukan oleh Majelis Kehormatan itu sendiri terhadap pejabat yang bermaksud untuk menyediakan perlindungan hukum bagi para orang yang menjalani profesi ini di dalam menjalankan fungsi tugas dan jabatannya secara profesional selaku pejabat umum, pengawasan tersebut sangat diperlukan, agar supaya dalam pelaksanaan tugas dan jabatannya mampu menjunjung tinggi martabatnya jabatannya. ${ }^{39}$

Pada hakekatnya notaris juga memiliki alat atau ornamen (senjata) lain sebagai salah satu wujud perlindungan hukum dalam pelaksaan tugas jabatannya di dasari UUJN, jabatan ini telah ada melekat istilah Verschoningsrecht dengan kata lain merupakan Hak Ingkar. Hak ini sejatinya bukan untuk kepentingan diri Notaris, tetapi untuk kepentingan para pihak yang saling berkaitan yang telah mempercayakan dirinya atas Notaris, bahwa pejabat ini dapat dipercaya dan mampu menyimpan semua pernyataan atau keterangan para pihak yang berkaitan yang pernah diberikan di muka notaris terkait dalam pembuatan akta.

Tindakan untuk tidak berbicara atau memberikan keterangan apapun yang berkaitan dengan akta yang telah disahkan di hadapan atau oleh notaris sebagai saksi dalam proses pengnuradilan dan proses penuntutan merupakan pengertian dari

\footnotetext{
36 Anshori Abdul Ghofur, Lembaga Kenotariatan Indonesia, Perspektif Hukum dan Etika,(Yogyakarta: UII Press 2010), hlm. 100.

37 Anshori Abdul Ghofur, supra note 36 hlm. 103.

38 Penjelasan Lebih jauh lihat hlm. 41.

39 Penjelasan Lebih Jauh Lihat hlm. 92.
} 
Verschoningsrecht atau suatu hak untuk tidak berbicara/tidak mengungkapkan informasi dalam bentuk apapun tertuang dalam Pasal 170 KUHAP dan Pasal 1909 ayat ke (3) KUHAPer merupakan hak menolak atau hak ingkar sebagai kekebalan hukum notaris. ${ }^{40}$

Penggunaan dari hak ingkar ini saksi yang merupakan notaris seharusnya dapat dibedakan dan dikenali sebagai sebuah perkara pidana atau perdata. Dalam proses pelaksanaan peradilan, selalu para pihak, seperti jaksa, penyidik, pengacara, hakim, biasanya meminta untuk pemanggilan saksi yaitu notaris dalam perkara perdata. ${ }^{41}$ Bahwa dalam hal ini akta yang dibuat oleh notaris bersifat akta otentik dan kebenaran yang diungkapkan yaitu wajib bersifat kebenaran formiil, sangat kontras dengan yang ada dalam hukum acara pidana, hakim selaku pencari kebenaran materil, bukan berarti dalam acara perdata hakim mencari kebenaran yang setengah-setengah atau palsu.

Terhadap perkara pidana itu sendiri, profesi ini secara wajib hadir tanpa dipanggil untuk memberi kesaksian dengan persetujuan Majelis Kehormatan profesinya. Dikarenakan dalam perkara hukum pidana ini yang dicari merupakan sebuah kebenaran materiil, pejabat profesi notaris secara wajib memberikan kesaksian tentang apa yang diras, dilihat, diketahui tentang suatu peristiwa sehingga pengukapan kasus tersebut menjadi transparan serta kebenaran materiil dapat dicapai.

Konstruksi perlindungan hukum yang dimaksud disini adalah dimasukkan/dicantumkannya nama notaris sebagai salah satu pihak pelapor dalam Undang-Undang (PPTPPU) pada BAB IV mengenai Pelaporan dan Pengawasan Kepatuhan bagian kesatu dalam pasal 17 ayat (1) yang meliputi pihak pelapor. Kemudian dalam Pasal 18 ayat (3) huruf (d) dijelaskan jika pihak individu pelapor merasa ragu tentang kebenaran sebuah informasi yang telah disampaikan oleh pengguna jasa maka pihak pelapor wajib menyampaikan laporan ke pada PPATK.

\section{PENUTUP}

Suatu perlindungan hukum bagi notaris yang mempunyai itikad baik dalam pembuatan akta jual beli saham dalam kasus hukum yang merupakan tindak pidana pencucian uang agar kiranya mendapatkan perlindungan hukum, dalam hal ini Notaris dapat dikategorikan sebagai pelapor jika pejabat ini bertindak diluar batas wilayah jabatannya yang telah diatur sedemikian rupa sebagai Notaris mengenai temuan kliennya yang terindikasi berada dalam transaksi yang mencurigakan dan selama laporan tersebut telah diberikan maka pihak pelapor berhak mendapatkan sebuah perlindungan atas keamanan pribadi, keluarga maupun harta kekayaannya, serta bebas dari ancaman yang berkenaan dengan kesaksian yang akan, sedang atau telah dinyatakannya, turut serta dalam proses menentukan dan memilih bagaimana wujud perlindungan berupa dukungan keamanan, memberikan keterangan tanpa mendapatkan intervensi dari pihak manapun, pendampingan penerjemah, bebas dari

\footnotetext{
40 Penjelasan Lebih Lanjut Lihat hlm. 44.

41 M. Nurung,supra note hlm. 68
} 
pertanyaan yang menjebak, perkembangan kasus dalam pembaruan informasi, informasi mengenai keluaran dari pengadilan yaitu putusan, dalam hal tertentu harus mengetehui bahwa terpidana dibebaskan, mendapatkan penggantian berupa biaya transportasi menurut kebutuhan, mendapat nasihat hukum dan/atau memperoleh dana untuk bantuan berbentuk apapun seperti berupa dana atau biaya hidup sementara sampai batas dengan berakhirnya perlindungan.

Konstruksi perlindungan hukum terhadap wilayah kerja profesi notaris yang secara langsung maupun tidak langsung berubah status menjadi korban dalam kasus tindak pidana hukum money laundering. Perlindungan hukum tersebut kepada notaris dalam lingkup tindak pidana hukum pencucian uang berdasarkan pada UUJN pada hakekatnya lebih bersifat condong ke wilayah intern/administratif seperti yang tertulis pada pasal ke 66 sampai dengan 66A UUJN Jo Undang-undang Nomor 20 Tahun 2004. Di samping itu notaris juga memiliki ornamen berupa instrument lain sebagai wujud perlindungan dalam hukum untuk menjalani tugas yang diembang dari jabatannya berlandaskan dari UUJN seperti Hak Ingkar (Verschoningsrecht). Hak ingkar merupakan suatu hak yang dapat dilakukan dengan berbagai batasan sejauh pejabat profesi ini diperiksa dan diintervensi oleh instansi apapun itu dan yang terkait yang berusaha untuk meminta keterangan atau pernyatan dari pejabat notaris yang berkaitan dengan akta yang telah atau pernah dibuat oleh atau di hadapan notaris yang bersangkutan.

\section{DAFTAR PUSTAKA}

Adjie, Habib. 2009. Sanksi Perdata dan Administrasi Terhadap Notaris Sebagai Pejabat Publik. Bandung: Refika Aditama 2009. Hukum Notaris Indonesia Tafsir Tematik Terhadap UU Nomor 30 Tahun 2004 tentang Jabatan Notaris. Bandung :Refika Aditama. Kumpulan Tulisan Tentang Notaris. 2010. Bandung: Mandar Maju 2011. Hukum Kenotariatan Indonesia Tafsiran Tematik Terhadap Undang-undang Nomor 30 Tahun 2004 Tentang Jabatan Notaris, Cetakan Ketiga. Bandung: Refika Aditama

Andi Khamisah Ayu Isnaini, Aminuddin Ilmar, Syamsuddin Muchtar. 2013. Kewenangan Notaris Dalam Pencegahan Tindak Pidana Pencucian Uang melalui Pembelian Saham. Makassar: Program Kenotariatan, Fakultas Hukum, Universitas Hasanuddin

Alius, Suhardi. 2005. Tinjauan Yuridis Pencegahan Dan Pemberantasan Tindak Pidana Pencucian Uang (Money Laundering) Bagi Penyedia Jasa Keuangan. Jurnal. Yogyakarta: Program

Magister Hukum Bisnis, Fakultas Hukum, Universitas Gadjah Mada

Aswandi. 2013. Penegakan Hukum Tindak Pidana Korupsi yang Berbarengan Deangan Tindak Pidana Pencucian Uang (Concurus Realis). Jurnal. Fakultas Hukum, Magister Ilmu Hukum, Universitas Tanjungpura.

Atmasasmita, Romli.2010. Globalisasi dan Kejahatan Bisnis. Jakarta: Prenada Bryan Gamer. 1999. Black's Law Dictionary (Seventh Edition). West Group 
Darmawan, I Made.2017 "Perlindungan Hukum Bagi Notaris atas Tindak Pidana Pencucian Uang yang Dilakukan Oleh Penghadapnya.Jurnal. Fakultas Hukum, Universitas Pamulang,

Garnasih, Yenti.2003.Kriminalisasi Pencucian Uang (Money Laundering). Jakarta: Program Pascasarjana, Fakultas Hukum, Universitas Indonesia,

Ghofur, A. Abdul. 2010.Lembaga Kenotariatan Indonesia, Perspektif Hukum dan Etika. Yogyakarta: UII Press

Ibrahim, Jhonny. 2007 Teori dan Metedologi Penelitian Hukum Normatif. Surabaya: Bayu Media Publishing

M. Arief, Amrullah. 2004.Tindak Pidana Pencucian Uang (Money Laundering).Malang: Bayu Media

M. Marzuki, Peter.2005.Penelitian Hukum. Edisi Revisi, Jakarta: Prenada Media Group,

Mertokusumo, Sudikno.2005.Mengenal Hukum Suatu Pengantar. Yogyakarta: Liberty,

Muhammad, Abdulkadir. Hukum Dagang Tentang Surat-surat Berharga.Bandung: PT Citra Aditya Bakti,

M. Wantu, Fence.2011.Mewujudkan Kepastian Hukum, Keadilan dan Kemanfaatan dalam Putusan Hakim di Peradilan Perdata. Artikel:Fakultas Hukum, Program Doktoral, Universtitas Gadjah Mada.

Nasution, B. Johannes.2008. Metode Penelitian Ilmu Hukum. Bandung: Mandar Maju

Noor, H. J. 2010.Jasa Notaris Sebagai Salah Satu Upaya Dalam Memperkuat Rezim Anti Pencucian Uang.Yogyakarta:Program Magister Kenotariatan, Fakultas Hukum, Universitas Gadjah Mada

Nurung, M.2006.Notaris Tidak Tepat Dijadikan Saksi Hukum Perdata. Majalah Renvoi 12 Edisi Mei

Pathorang,Halim.2013.Penegakan Hukum Terhadap Kejahatan Pencucian Uang di Era Globalisasi. Jakarta: Total Media

R. Subekti.2005. Hukum Pembuktian. Jakarta:Pradnya Paramita

Rahardjo, Satjipto. 2000.Ilmu Hukum. Bandung:Citra Aditya Bakti

Remmelink, Jan.2003 Hukum Pidana: Komentar atas Pasal-pasal Terpenting dari kitab Undang-

Undang Hukum Pidana Belanda dan Padanannya dalam Kitab Undang-Undang Hukum Pidana Indonesia.Jakarta:Gramedia

Rudhi, Prasetya. 2000 .Teori dan Praktek Perseroan Terbatas. Jakarta: Sinar Grafika

Stessens, Guy.2000 Money Laundering: New International Law Enforcement Model, Cambridge. Cambridge University: Press

Sjahdeini, S.R.2007.Seluk Beluk Tindak Pidana Pencucian Uang dan Pendanaan Terorisme.Jakarta: Pustaka Utama Grafitri

Sjaifurrachman dan Adjie, H.2011.Aspek Pertanggung Jawaban Notaris Dalam Pembuatan Akta. Polewali: Mandar Maju

Soimin, S.1996. Kitab Undang-undang Hukum Perdata." Jakarta: Sinar Grafika, 1996.

Sutrisno. Jurnal,2016.Penegakan Hukum Tindak Pidana Pencucian Uang dari Hasil Kejahatan Korupsi Berdasarkan Undang-Undang RI Nomor 8 Tahun 2010 Tentang Pencegahan dan 
116 | Perlindungan Hukum terhadap Notaris yang Beritikad Baik Membuat Akta Jual Beli Saham ...

Pemberantasan Tindak Pidana Pencucian UangFakultas Hukum, Magister Ilmu Hukum, Universitas Tanjungpura

Sutedi, Adrian.2010.Hukum Perbankan Suatu Tinjauan Pencucian Uang, Merger, Likuidasi dan Kepailitan. Jakarta: Sinar Grafika

Wiguna, W. K.2010.Hak Ingkar Notaris dalam Hukum Pembuktian Pidana di Indonesia.

Yogyakarta:Program Magister Hukum Kenotariatan Fakultas Hukum,

Universitas Gadjah Mada

Wiyono, R.2014 Pidana Pencucian Uang Jakarta: Sinar Grafika .2014.Pembahasan Undang-Undang Pencegahan dan Pemberantasan Tindak Pidana

Pencucian Uang.Jakarta:Sinar Grafika

Yustiavandana, Nevi \& A. Adiwarman.2010 Tindak Pidana Pencucian Uang di Pasar Modal.Bogor:Ghalia Indonesia

Marwan dan Jimmy.2009. Kamus Hukum. Surabaya: Reality Publisher

Yuniar, T. Kamus Lengkap Bahasa Indonesia. Agung Media Mulia

Alam, W.T. 2015 “UU Pencucian Uang (1): Anomali Kepastian Hukum.

www.ppatk.go.id/

http://www.unafei.or.jp/english/pdf/RS_No58/No58_05VE_Tat-wingl.pdf/), 23/01/2017

https://www.ini.id/apps/public/file/kode_etik/Perubahan_KEN_hasil_KLB_2015

http://habibadjie.dosen.narotama.ac.id/files/2013/07/MEMAHAMI-HAK-INGKAR-

DAN KEWAJIBAN-INGKAR-NOTARIS.pdf/.

http://www.hukumonline.com/berita/baca/holl7939/notaris-diminta-waspadai-

pencucian-uang-lewat-pembelian-saham.

Hadjar, A.F. 2015. Cuci Mencuci Uang Dan Menangkap Gate Keeper. diunduh tanggal 02 Maret 2015.

http://www.hukumonline.com/berita/baca/holl7939/notaris-diminta-waspadai-

pencucian-uang-lewat-pembelian-saham

http://www.tribunnews.com/nasional/2015/05/19/kpk-panggil-lagi-notaris-terkait-

kasus-nazaruddin

http://nasional.kompas.com/read/2013/01/30/12500082/empat.notaris.diperiksa.terkait.

kasus.pencucian.uang.djoko.susilo 